\title{
Effects of Dehydroepiandrosterone and Cortisol on Carcass and Organ Weight in Adrenalectomized Female Rats
}

\section{Eturo NISHIDA}

\author{
Department of Obstetrics and Gynecology, School of Medicine, The University of Kanazawa, \\ Kanazawa, Japan (Director : Professor F. Akasu, M.D.)
}

Studies were made on the effects of administration of dehydroepiandrosterone (DHA) and cortisol (COL) on the weight of body, bone and muscle, and several organs in noraml and adrenalectomized female rats. As a preliminary experiment DHA was given to several groups of normal and ovariectomized female albino rats for about 2 weeks, and the body weight gain and weight of organs were determined. An Occasional and relativelyslight increase of body weight gain was observed as the result of DHA treatment in these groups.

In the second series of experiments, female Wistar strain rats (litter-sisters) were divided into six gorups. Bilaterally total adrenalectomy was performed in 5 groups under ether anesthesia, and one per cent saline and food were supplied ad libitum. Of these adrenalectomized groups, three groups were given daily injections of desoxycorticosterone acetate (DOG) and treated with either DHA, or COL, or the combination of DHA and COL. The remaining there groups served as controls, i.e. adrenalectomized control groups treated with or without DOC, and a non-adrenalectomized normal control group.

Body weight was daily measured. Animals were killed by exanguination under ether anesthesia, and autopsy was performed. The liver, kidney, heart, brain preputial gland and other organs were removed and weighed. After the removal of the intestinal organs, the skin and fat were removed from the muscles. The skeleton with muscles and the skin with fat were weighed, respectively, and then dried at $100^{\circ} \mathrm{C}$ for $48 \mathrm{hrs,}$, and weithed again.Results obtained were as follows;

(1) The body weight gain was found on the average to be 41.4 67.2, 51.6, 53.6, 18.2, and 44.8g for the groups treated with (1) DOG alone, (2) DOG+DHA, (4) DOC+DHA $+\mathrm{COL}$, (5) with no steroid, and (6) for non-adrenalectomized rats, respectively. Wet and dried weights of the skeleton with muscles were 89.6 (27.0), 98.8 (30.2) 90.6 (27.8), 94.4 (29.3), 65,2 (20.1), and 91.8(28.6)g for the groups, respectively (Figure in parentheses means dried weight of the tissue.). Administration of DHA to adrenalectomized female rats did induce an increase in body weight and in weight of both wet and dried carcasses.

(2) Absolute weitht of the liver and the weight ratio of the liver to body were found to be 8.64 (5.47), 11.06 (6.37), 8.84 (5.50), 11.25 (6.65), 5.30 (4.16), and $9.56 \mathrm{~g})(5.89 \mathrm{~g} \%)$ for the groups described, respectively (The weithg ratio is in parentheses.). Hypertrophy of the liver is greatest in DHA- and DHA-COL-treated groups. 
(3) The weight of the kidney was higher in the DHA-treated group than in controls. No significant weight gain of the heart and brain was observed.

(4) The weights of preputial glands with or without contents were 80 (59), 135 (88), 92 (64), 169 (107), 62 (43), and 108 (78) mg for the groups, respectively (Figure in parentheses means the weight without contents.). DHA induced a remarkable hypertrophy of the preputial gland and an increase of the contents. It would seem that COL acts on the hypertrophy of the tissue synergistically with DHA in adrenalectomized animal.

(5) The myotrophic activity of DHA on the m. levator ani of castrated male rat was observed to be about $37.4 \%$ of that of testosterone propionate (TP), and DHA has about $1.7 \%$ of the activity of TP on the rat accessory sex organ.

(6) Effects of DHA on growth, on protein metabolism in the liver, and on sexual behavior in the female were discussed.

(pp. 758 769) 


\title{
Dehydroepiandrosterone 投与の両側副腎摘除
}

\section{雌ラットの成長発育に及ぼす影響}

\author{
金沢大学医学部産科婦人科学教室 (主任 赤須文男教授) \\ 西田悦郎
}

(昭和 42 年 1 月 27 日受付)

\section{I 緒言}

女子における全身的および臧器の成長発育および老化については, 内分泌学的には growth hormone, thyroxin, corticosteroids, 副腎性 androgen, estrogen その他のホルモンが密接に関与しているてとは周知 の所であるが, 副腎由来の androgen の主要分画とみなされる dehydroepiandosterone (DHA) の女子の成 長および老化に関する作用および意義についての詳細な研究は比較的乏しく，未解明の点もかなり多い. す なわち， androgen に蛋白同化作用の存在すること备その他から副腎由来の androgen が女子の蛋白同化作 用とくに思春期前期の急速な成長に重要な役割を果しており，また，閉経後の老化と副腎性 androgen の減 少とが関連性を有しているであろうことは推測 はされるが，その各種副腎性 androgen についての詳細な 実験，作用機序，その分泌調節因子などについては，今後の研究にまたれている面がすくなくない.

われわれは女子における副腎性 androgen とくに DHA の作用および意義についていくつかの検討を行 なつてきているが2゙ー8), DHA を雌ラットに投与した場合の体重その他藏器重量に及ぼす影響について, 副 䟝の有無との関連性を検討し, さらに DHA と cortisol 併用投与の影響についても考察を加えたので報告 する.

\section{Dehydroepiandrosterone 投与の非副腎摘除雌ラット体重増加に及ぼす影響， および Dehydroepiandrosterone のいわゆる蛋白同化能について}

DHA を投与した場合の雌動物の体重についてはいくつかの報告がみられるが $\left.{ }^{8}\right)^{9}$, その結果は必ずしも 一致しておらず，軽度増加するというもの，対照に比し著変が認められないとするものなどがある。また DHA の男化作用は testosterone などに比して極めて小さいとされている。著者はまずてれらについて再 検討する目的で正常雌ラットに DHA を投与し，その体重変化の有無を測定し，また雄ラットを使用して いわゆる蛋白同化能を testosterone のそれと比較してみた.

\section{A. DHA 投与の正常ラット体重に及ぼす影響}

まず体重平均 $130 \mathrm{~g}$ 前後の Wistar 系成熟雌ラット10匹 2 群にわけ, 実験群には DHA 水性影濁液 2 $\mathrm{mg}$ を毎日背部皮下に連続注射し，毎日午前のほぼ一定時間に体重測定を行なつた。

なお，飼料はラット繁殖用固型飼料（オリエンタル NMF） と水とを自由に摄取させた.

結果はFig. 1-1 および Table 1 亿示す如くで12日間の成績では著明な变化は認められなかつた.

次で体重平均約 $90 \mathrm{~g}$ の雌ラットで同様の実験を行なつたが，Fig. 1 - II に示す如く15日後では DHA 投与 群の体重増加やや大きい傾向がみられたが，有意の差ではなかつた．さらに，体重 $90 \mathrm{~g}$ 前後で両側卵巣を摘 除し， 3 週間放置し，体重平均約 $170 \mathrm{~g}$ の去勢雌ラットに 2 週間 DHA 1 日 $2 \mathrm{mg}$ 連続投与した場合にも体 重増加は認めることができなかつた。

すなわち $2 \mathrm{mg}$ 程度の DHA を投与した場合は，軽度の体重増加傾向を示す場合もあるが，必ずしも常に 一定の増加傾向を示すとは限らず，対照と殆んど全く同様のとともしばしばであり，また卵巣の有無はこの 場合とくに関係がないように思われた。

㵴器重量については, 肝, 腎は体重の変化とほぼ平行し, DHA 投与群と対照群との間に著変は認められ なかつたが, 副腎重量は Table 2 に示す如くDHA 投与群では対照群に比し減少し, 脍腺重量も減少傾向を 
Fig. 1. Effects of administration of DHA on the body weight gain in female rats

Series I (normal rats) Initial body wt. about $130 \mathrm{~g}$

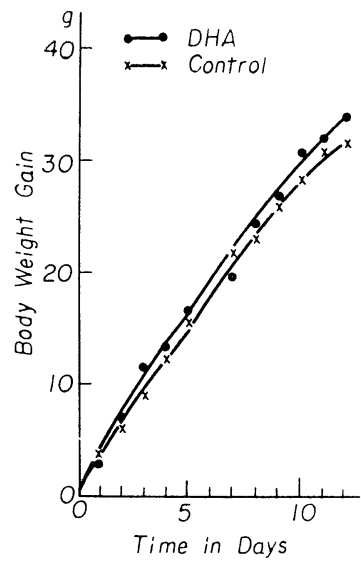

Series II (normal rats) Initial body wt. about $90 \mathrm{~g}$

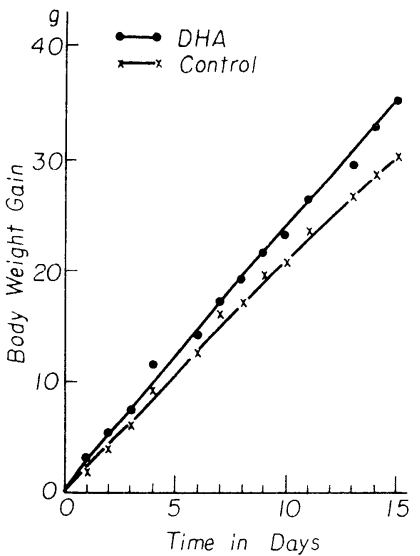

Series III (spayed rats) Initial body wt. about $170 \mathrm{~g}$

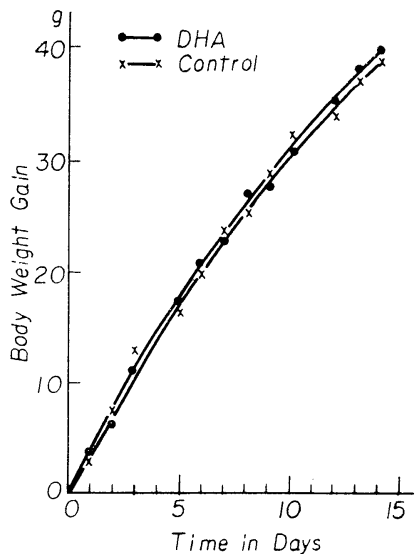

Table 1. Effects of administration of DHA on the body weight in female rats

\begin{tabular}{l|c|c|c|c|c|c}
\hline \multirow{2}{*}{ Series } & Group & No. & Admin. of DHA & \multicolumn{2}{|c}{ Average Body wt. (g) } \\
\cline { 3 - 7 } & & & & Initial & Finat & Gain \\
\hline I. Normal Rat & DHA & 5 & $2 \mathrm{mg} / \mathrm{d} \times 12 \mathrm{~d}$ & 126.2 & 160.1 & 33.9 \\
& Control & 5 & - & 131.7 & 163.3 & 31.6 \\
\hline \multirow{2}{*}{ II. Normal Rat } & DHA & 5 & $2 \mathrm{mg} / \mathrm{d} \times 15 \mathrm{~d}$ & 89.1 & 124.6 & 35.5 \\
& Control & 5 & - & 86.3 & 116.5 & 30.2 \\
\hline \multirow{2}{*}{ III. Spayed Rat } & DHA & 5 & $2 \mathrm{mg} / \mathrm{d} \times 14 \mathrm{~d}$ & 167.2 & 207.2 & 40.0 \\
& Control & 5 & - & 172.8 & 211.6 & 38.8 \\
\hline
\end{tabular}

Table 2. Effects of administration of DHA on the weight of adrenal and of thymus in female rats

\begin{tabular}{c|c|c|c|c}
\hline $\begin{array}{c}\text { Group } \\
\text { (No.) }\end{array}$ & $\begin{array}{c}\text { Body wt. } \\
\text { (Finat) }\end{array}$ & Adrenals & Thymus \\
\hline \hline DHA (5) & \multirow{2}{*}{$\begin{array}{c}\text { Absolute wt. (mg) } \\
\text { DHA 2mg/d }\end{array}$} & $\begin{array}{c}\text { Abt./00g of B. wt.(mg) } \\
\text { Difference** }\end{array}$ & $\begin{array}{c}37.2 \pm 2.2^{*} \\
29.8\end{array}$ & $\begin{array}{c}335.9 \pm 41.7 \\
24.6\end{array}$ \\
\hline \multirow{2}{*}{ Control (5) } & \multirow{2}{*}{$116.5 \mathrm{~g}$} & $\begin{array}{c}\text { Absolute wt. (mg) } \\
\text { wt./100g of B. wt. (mg) }\end{array}$ & $\begin{array}{c}43.8 \pm 1.9 \\
37.6\end{array}$ & $\begin{array}{c}416.1 \pm 27.5 \\
357.1\end{array}$ \\
\hline
\end{tabular}

* Standard error

** Difference from controls in absolute weight 
示した.

てれらの実験結果から DHA 投与により場合によつては体重増加傾向を認めうるが，その効果は生体の 状態によつて恒常的ではなく，とくにDHA の副腎に及ぼす影響などからも，その非恒常性は副腎機能に 密接に関与しているように思わ机た。军なわち副腎由来の steroid である DHA を副腎を有する動物に投 与すれば, 副腎は, 直接的にまた中枢を介して影響をうけ内因性 DHA 分泌も変動し, 実験条件はかなり 複雑となるであろうから，DHA の真の作用を知るためには副腎を摘除した動物——理想的には DHAの み欠除した動物—— DHA を投与してその影響を検討するてとが大切とみなされた。

\section{B. Dehydroepiandrosterone のいわゆる蛋白同化能について}

androgen を投与すると nitrogen balance が負となり, 窒素蓄積ひいては体内蛋白量が増加するが，乙 のいわゆる蛋白同化能 protein anabolic action の大小を知る目安としてはいくつかの方法があるが今日有 効な steroid の screening 在目的として頻用されているものに雄ラットのいわゆる肛門挙筋肥大作用の大 小を比較する方法がある ${ }^{10111}$ ，乙の方法は現在最もよく用いられているが，一方，肛門挙筋は androgen の pretein anabolic actionのみならず androgenic action にも影響され，ある steroid を投与した場合の 肛門挙筋の肥大は，他の全身の骨骼筋肥大やその他の蛋白量増加とは必ずしも平行せず，また男化作用の強 い steroid では骨骼筋に比し，肛門挙筋の肥大率は大きい，乙れらについては種々検討されているが ${ }^{12)-16), ~}$ いわゆる肛門挙筋 M. levator ani ${ }^{17}$ ) の肥大を直ちに蛋白同化能の指標とみなすのは疑義があるともされ

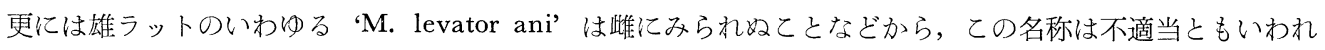
ている ${ }^{15)}$.

著者もいくつかの anabolic steroids の検討において肛門挙筋肥大率が他の骨骼筋の肥大率をかなり上廻 るととが多いため, 蛋白同化能の指標の選定に困惑を感ずるととがすくなくなかつた，しかし，乙の肛門挙 筋法は手軽であり, また現在の所, 他により確立された方法もないようなので, 今日頻用されており, 著者 もまたての方法に基いて，DHA の蛋白同化能および蛋白同化能と男化能との比を testosterone のそれと比 較してみた。 なお, てれらの比較に際しては, 階段的に種々の量の steroid を投与し, 增加曲線を求めて比 較する方がより正確であると推奨されており ${ }^{18)}$ ，また，対照の steroid としては methyltestosterone が用い られるととが多いが，いずれにしろ，肚門挙筋法自体必ずしも完全に蛋白同化能を表現するものではないの で, 本法は一応の目安をうるのによい方法とみなし, その範囲で大略の比較を行なつた。 また testosterone としては testosterone propionate (TP) を使用して DHA と比較したが, TP と DHA との分子量はやや 異るから撖密な比較には同一 $\mathrm{mol}$ 濃度とするなど分子量と同一比の量について比較すべきであろうが，こ の点についても上記同様の考え方から両者同一 $\mathrm{mg}$ 数について比較した.

実験方法 : 体重平均約 $110 \mathrm{~g} の$ Wistar 系同腹雄ラット25匹を去勢し，4 週間放置した後， 5 群にわけ，

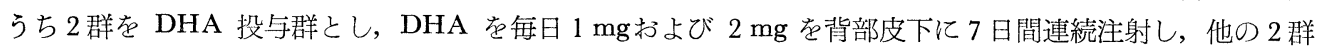
を testosterone 投与群とし, testosterone propionate (TP) を毎日 $1 \mathrm{mg}$ およで $2 \mathrm{mg}$ を同様投与し，残余の 1 群を対照群とし毎日ゴマ油 $0.1 \mathrm{ml}$ を投与した。 steroid 投与終了後, 全ラットを屠殺し, 肛門挙筋, 前立 腺, 精囊を摘出し, それぞれ重量を測定し, 各群の重量増加量を比較検討し, また肛門挙動重量増加量と前 立腺および精囊重量增加量との比をとり，乙れを蛋白同化男化比 anabolic androgenic ratio として各群の 值について比較し, 前立腺または精囊侱々に対する比についても検討した。 なお, 精囊重量については内容 は排泄の程度により変動するが，内容を除去した精霬壁は菲薄であり，その重量を比較するよりは内容を含 んだまま重量を測定した方が，男化能の指標としては，より適当とみなされたので，内容を含んだままの重 量を測定し比較した.

実験成績：得られた結果は Table 3 亿示す如くであつた。 なお DHA $1 \mathrm{mg}$ 投与群では副性器および肛門 筋重量が対照群に比し著変がみられなかつたので省略し, DHA および TP 投与群のうち $2 \mathrm{mg}$ 投与群につ いて比較した。

その結果 DHA 投与により精囊重量は平均 $3.2 \mathrm{mg}$ の増加で1.11倍に肥大，前立腺は $2.0 \mathrm{mg}$ の増加で同様 
Table 3. Effects of DHA and testosterone propionate on levator ani and accessory sexual organs in castrated male rats

\begin{tabular}{|c|c|c|c|c|c|c|c|c|c|}
\hline \multirow{2}{*}{\multicolumn{2}{|c|}{ Group (No.) }} & \multicolumn{4}{|c|}{ Absolute Weight (mg) } & \multicolumn{4}{|c|}{ Ratio to Controls } \\
\hline & & $\begin{array}{c}\text { Levator } \\
\text { ani }\end{array}$ & $\begin{array}{c}\text { Vesicula } \\
\text { seminal. }\end{array}$ & Prostata & $\begin{array}{l}\text { Ves. sem. } \\
\text { + Prost. }\end{array}$ & $\begin{array}{l}\text { Lev. } \\
\text { ani. }\end{array}$ & $\begin{array}{l}\text { Vesic. } \\
\text { sem. }\end{array}$ & Prost. & $\begin{array}{l}\text { Ves. sem. } \\
\text { + Prost. }\end{array}$ \\
\hline \multicolumn{2}{|c|}{$\begin{array}{c}\mathrm{DHA}(5) \\
2 \mathrm{mg} / \mathrm{d} \times 7 \mathrm{~d}\end{array}$} & $\begin{array}{c}43.8 \\
\pm 2.0^{*}\end{array}$ & $\begin{array}{l}32.5 \\
\pm 4.4\end{array}$ & $\begin{array}{l}12.8 \\
\pm 2.0\end{array}$ & $\begin{array}{l}45.3 \\
\pm 3.4\end{array}$ & 1.84 & 1.11 & 1.19 & 1.13 \\
\hline \multicolumn{2}{|c|}{$\begin{array}{c}\text { T.P.(5) } \\
2 \mathrm{mg} / \mathrm{d} \times 7 \mathrm{~d}\end{array}$} & $\begin{array}{l}77.3 \\
\pm 3.3\end{array}$ & $\begin{array}{r}296.3 \\
\pm 39.6\end{array}$ & $\begin{array}{l}44.3 \\
\pm 3.8\end{array}$ & $\begin{array}{r}340.6 \\
\pm 42.6\end{array}$ & 3.25 & 10.11 & 4.10 & 8.49 \\
\hline \multicolumn{2}{|c|}{ Control (5) } & $\begin{array}{l}23.8 \\
\pm 0.9\end{array}$ & $\begin{array}{l}29.3 \\
\pm 6.4\end{array}$ & $\begin{array}{l}10.8 \\
\pm 1.3\end{array}$ & $\begin{array}{l}40.1 \\
\pm 6.4\end{array}$ & 1.00 & 1.00 & 1.00 & 1.00 \\
\hline & \multicolumn{4}{|c|}{ Gain of Weight (mg) } & \multicolumn{2}{|c|}{$\mathrm{DHA} / \mathrm{TP}(\%)$} & \multicolumn{3}{|c|}{ Anab.-Androg.-Ratio } \\
\hline & Lev. ani & $\begin{array}{l}\text { Vesic. } \\
\text { sem. }\end{array}$ & Prost. & $\begin{array}{l}\text { Ves. sem. } \\
+ \text { Prost. }\end{array}$ & Lev. ani & $\begin{array}{l}\text { Ves. sem. } \\
+ \text { Prost. }\end{array}$ & $\begin{array}{l}\text { L. ani } \\
\text { V. sem. }\end{array}$ & $\begin{array}{l}\text { L. ani } \\
\text { /Prost. }\end{array}$ & $\begin{array}{l}\text { L. ani// } \\
\text { V.S. }+ \text { P. }\end{array}$ \\
\hline DHA & 20.0 & 3.2 & 2.0 & 5.2 & 37.4 & 1.7 & 6.25 & 10.00 & 3.85 \\
\hline $\mathrm{TP}$ & 53.5 & 267.0 & 33.5 & 300.0 & 100.0 & 100.0 & 0.20 & 1.60 & 0.18 \\
\hline
\end{tabular}

* Standard error

1.19倍とでくわずかしか増大しないのに比し, 肚門挙筋重量は平均 $20.0 \mathrm{mg}$ 増加し, 1.84 倍とかなりの増大 を示した。 乙れを TP 投与群において，精囊および前立腺がそれぞれ10.11および4.10倍と著しく肥大し， それに比し肚門挙筋重量増加が3.25倍に止つたのと比較すると, DHA は男化能が極めて小さく, 蛋白同化 能は比較的大きいといえる。 TP 投与による重量増加量を $100 \%$ として DHA のそれと比較しでみると, DHA の肛門挙筋肥大能いわば蛋白同化能は TP の平均 $37.4 \%$ であり, その副性器肥大能いわば男化能は TP のわずか $1.7 \%$ にずない，また本実験条件における anab.-androg.-ratio を比較してみると DHA の

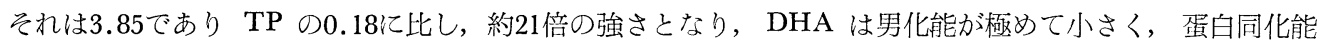
のかなり強い natural steroid というととができる。

\section{C. 考察および小括}

蛋白同化能の検討として肛門挙筋法から得られた詳細な数值自体が，全身的蛋白同化能の指標として有す る意義については，厳密な意味では種々問題点もあろうと思われるが，その定性的または大略の目安として の蛋白同化能の指標という点では意義のあるものとみなされる. 上記実験からも DHA がその男化能に比 してかなりの蛋白同化能を有していることが確認された。 なお, ての様に蛋白同化能がかなり強く, 男化能 の極めて小さい steroid が女子に抏いてかなり多量分泌されることは，とくに女子の蛋白同化や成長の面か らみても極めて好都合のととといえよう。

また，乙の様な steroid を投与した際には被検動物の体重が増加するのが妥当と思われるが，実際の実験 成績では必ずしも恒常的に増加を示すとは限らず，著変の諗められないこともしばしばあつた。

副䡒皮質からは，いわば catabolic steroid として corticosteroids が分泌されているが，乙れは anabolic steroid としての DHA その他副腎性 androgen とは時には拮抗的に作用するとみなされ，また一般にあ る内分泌腺より分泌されるホルモンを体外より投与した場合は必ずその内分泌㵴器の機能は影響をうけるか ら，DHA を投与した場合も副腎からの内因性 DHA や corticosteroids の分泌は何らかの影響をうけるも のとみなされる，従つて副眯を有する動物に DHA を投与した場合には，その時の副腎の状態により種々 の反応が起り，その実験条件はかなり複雑になり，現れた結果は必ずしも常に DHA の直接的作用を表現 
しているとは限らないといえよう。

著者は実験条件をより簡明にする目的で両側副腎を摘除した後 DHA を投与し，その体重および各種臓 器重量の変化について検討した。

またその場合の corticosteroids との相互的作用を検討する目的で cortisol を併用投与してその影響を比 較検討した。

\section{Dehydroepiandrosterone および Cortisol 投与の両側副腎摘除} 雌ラット体重, 肝, 腎その他臓器の重量に及ぼす影響

上記の如く，DHA および cortisol が榫ラットの成長に及ぼす影響を検討する目的で，実験条件の複雑 化を防ぐため両側副腎摘除ラットに DHA および cortisol を投与して検詂を加壳た。

\section{A. 実験方法}

体重平均 $110 \mathrm{~g}$ 前後の 1 腹 6 〜 7 匹ずつの 5 群より成る同腹雌ラットを使用して実験を行なつた。乙の同 腹ラット在 6 群（1 群 5 匹）に分け，そのうち 5 群を ether 麻酔下に腹臥位に固定し側腹部より両側副腎を 摘除し，感染予防の目的で penicillin $10^{4}$ 単位 1 回注射し，飼育には $1 \% \mathrm{NaCl}$ 水溶液および固型飼料 (ラ ット繁殖用オリエンタル NMF) 在自由に掑取せしめた。

第 1 群は desoxycorticosterone acetate (DOC) t 1 日 $0.25 \mathrm{mg}$ 在背部皮下に注射し，DOG 単独投与群と し，第 2 群は 1 日 DOC $0.25 \mathrm{mg}$ および DHA $2.0 \mathrm{mg}$ を投与し DHA 投与群とし，第 3 群は 1 日 DOC $0.25 \mathrm{mg}$ および cortisol (GOL) $0.25 \mathrm{mg}$ 投与し COL 投与群とし, 第 4 群は 1 日 DOC $0.25 \mathrm{mg}$, DHA 2.0 $\mathrm{mg}$ および $\mathrm{GOL} 0.25 \mathrm{mg}$ を投与し， DHA $+\mathrm{COL}$ 混合投与群とし，第 5 群は steroid を投与せず steroid 非投与副腎摘除対照群（なおこの群のみは 3 匹追加し 8 匹）とした。なお，副腎を摘除しなかつた群を非副 腎摘除対照群とした。

体重崺毎日午前10時頃のほぼ一定時間に測定し第14日目までの体重曲線について各群比較検討し, その後 ether 麻醉下に心穿刺により脱血死せしめて屠殺した。屠殺後, 肝・腎その他蔵器を摘出し, 周囲の脂肪組 織などを除去した後，重量測定までの間，生理的食塩水汇浸した沪紙閒にはさみ水分の蒸発を防ぎ，できる だけ早い時期に重幊测定を行なつた。また，内臓抢上び脳を除去した身体の重量，および更にそれらから皮

Table 4. Effects of administration of DHA and cortisol on the body weight in the adrenalectomized female rats

\begin{tabular}{l|l|c|c|c|c}
\hline \multirow{2}{*}{ Group } & \multicolumn{2}{c|}{ Average Body Weght (g) } & Ratio \\
\cline { 3 - 6 } & & Initial & Final** & Gain & \\
\hline 1 & DOG & $112.8 \pm 3.7$ & $154.2 \pm 3.1$ & $41.4 \pm 2.4$ & 1.00 \\
2 & DOG+DHA & $106.8 \pm 4.7$ & $174.0 \pm 6.6$ & $67.2 \pm 3.4$ & 1.62 \\
3 & DOC+COL & $105.4 \pm 4.4$ & $157.0 \pm 6.1$ & $51.6 \pm 2.6$ & 1.24 \\
4 & DOC+DHA+COL & $112.2 \pm 4.4$ & $165.8 \pm 1.9$ & $53.6 \pm 3.7$ & 1.30 \\
5 & $1 \%$ NaCl alone & $104.2 \pm 2.5$ & $122.4 \pm 6.5$ & $18.2 \pm 2.1$ & 0.44 \\
6 & Non-adrenalect. Rat & $110.6 \pm 6.1$ & $159.4 \pm 6.2$ & $48.8 \pm 2.3$ & 1.18 \\
\hline
\end{tabular}

DOG $0.25 \mathrm{mg} / \mathrm{d}$

DHA $2 \mathrm{mg} / \mathrm{d}$

COL $0.25 \mathrm{mg} / \mathrm{d}$

No. of rats : 5 in each group

* Standard error

** 14th day after the start of the injection

*** Ratio of the gain in each group to that in DOC-group 
膚・脂肪を除去し，骨・筋肉のみとしたものの湿一 および乾燥一重量について検討を加えた。

なお乾燥は $100^{\circ} \mathrm{C} て ゙ 48$ 時間行なつた。また， $100^{\circ} \mathrm{C}$ 48時間の骨・笳乾爆重量の平均 ( $\mathrm{mg}$ まで測定) を $100.00 \%$ とすると 24 時間の值は $102.61 \% ， 72$ 時間の 值は $99.62 \%$ であつた。

\section{B. 実験成績}

\section{1. 体重に及ぼす影響}

$\mathrm{DHA}$ および COL 投与の両側副腎摘除雌ラット の体重に及ぼす影響として前記各群の14日目までの 体重増加を示すと Table 4 および Fig. 2 の如くで あつた。

すなわち，副腎摘除ラットを $1 \% \mathrm{NaCl}$ のみで 飼育すると延命はするが体重の増加は極めて悪く, 10 日ないし 2 週間目に 8 匹の中 2 匹死亡し，ての群 の体重増加量は平均 $18.2 \mathrm{~g}$ 亿すぎなかつたが，乙れ にDOG 在単独投与すると，かなり重量增加率は
Fig. 2. Effects of administration of DHA and cortisol on the body weight gain in the adrenalectomized female rats

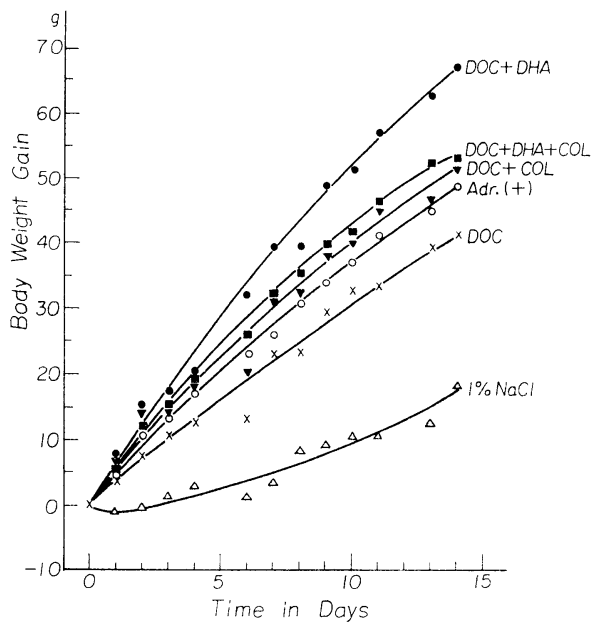

Table 5. Effects of DHA and cortisol on the wet and dry weight of tissues in the adrenalectomized female rats

\begin{tabular}{|c|c|c|c|c|c|c|c|c|}
\hline \multirow{2}{*}{ Group } & & & \multirow{2}{*}{$\begin{array}{l}\text { Body } \\
\text { Wt. at } \\
\text { the } \\
\text { Sacri- } \\
\text { fice }\end{array}$} & \multicolumn{3}{|c|}{ Wet Weight } & \multicolumn{2}{|c|}{ Dry Weight } \\
\hline & & & & $\begin{array}{l}\text { Bone \& } \\
\text { Muscle }\end{array}$ & $\underset{\text { Fat }}{\text { Skin } \&}$ & $\begin{array}{l}\text { Intestine } \\
\& \text { Brain }\end{array}$ & $\begin{array}{c}\text { Bone \& } \\
\text { Muscle }\end{array}$ & $\underset{\text { Fat }}{\text { Skin }} \&$ \\
\hline \multirow{3}{*}{ 1. DOG } & $\mathrm{a}$ & Alsolute wt. (g) & 157.8 & 89.6 & 26.8 & 41.4 & 27.0 & 9.8 \\
\hline & $\mathrm{b}$ & Standard Error (g) & 3.3 & 2.7 & 0.8 & - & 0.6 & - \\
\hline & $\mathrm{c}$ & $\% *$ & 100.0 & 56.8 & 17.0 & 26.2 & $(30.1)^{* *}$ & $(36.4)$ \\
\hline \multirow{3}{*}{ 2. $\mathrm{DOC}+\mathrm{DHA}$} & $\mathrm{a}$ & Absolute wt. (g) & 173.6 & 98.8 & 28.6 & 46.2 & 30.2 & 11.0 \\
\hline & b & S.E. $(g)$ & 5.2 & 2.5 & 0.7 & -- & 0.4 & - \\
\hline & c & $\%$ & 100.0 & 56.9 & 16.5 & 26.6 & $(30.6)$ & 38.4 \\
\hline \multirow{3}{*}{ 3. $\mathrm{DOC}+\mathrm{COL}$} & a & Absolute wt. (g) & 160.6 & 90.6 & 26.4 & 43.6 & 27.8 & 9.2 \\
\hline & b & S.E. (g) & 3.4 & 2.2 & 1.1 & - & 0.5 & - \\
\hline & c & $\%$ & 100.0 & 56.4 & 16.4 & 27.1 & $(30.7)$ & $(34.8)$ \\
\hline \multirow{3}{*}{$\begin{array}{l}\text { 4. } \mathrm{DOC}+\mathrm{DHA} \\
+\mathrm{COL}\end{array}$} & $\mathrm{a}$ & Absolute wt. (g) & 169.2 & 94.4 & 27.6 & 47.2 & 29.3 & 10.2 \\
\hline & b & S.E. (g) & 3.6 & 1.3 & 2.2 & - & 0.6 & - \\
\hline & c & & 100.0 & 55.8 & 16.3 & 27.9 & $(31.0)$ & $(36.8)$ \\
\hline \multirow{3}{*}{$\begin{array}{l}\text { 5. } 1 \% \mathrm{NaCl} \\
\text { alone }\end{array}$} & $\mathrm{a}$ & Absolute wt. (g) & 127.6 & 65.2 & 23.8 & 38.6 & 20.1 & 9.4 \\
\hline & b & S.E. (g) & 4.9 & 2.5 & 2.0 & - & 0.4 & - \\
\hline & c & $\%$ & 100.0 & 51.1 & 18.6 & 30.3 & $(30.8)$ & $(39.4)$ \\
\hline \multirow{3}{*}{$\begin{array}{l}\text { 6. Nonadrenal- } \\
\text { ectomized } \\
\text { Rats }\end{array}$} & $\mathrm{a}$ & Absolule wt. (g) & 162.2 & 91.8 & 25.2 & 45.2 & 28.6 & 10.0 \\
\hline & $\mathrm{b}$ & S.E. (g) & 6.4 & 3.4 & 1.3 & - & 0.8 & - \\
\hline & c & $\%$ & 100.0 & 56.6 & 15.5 & 27.9 & $(31.2)$ & $(39.6)$ \\
\hline
\end{tabular}


改善され体重増加量は平均 $41.4 \mathrm{~g}$ と なつた。 これに DHA を追加投与 するとその成長度は極めて著しく增 大し 2 週間の体重増加量は平均 67.2 $\mathrm{g}$ で，DOG 単独投与群の 1.6 倍の 増加量を示し，また副腎を摘除しな かつた正常ラットの群の平均 $48.8 \mathrm{~g}$ をもはるか化越える体重増加を示し た，また， COL+DOG 群では体重 増加量の平均值は $51.6 \mathrm{~g}$ で, DOG 単独投与群を上廻る值を示した。 こ れは， cortisol が全く欠乏している 状態よりも適当量存在している方が 成長に望ましととを示すものと思わ れ, cortisol の過量は catabolic に 作用するとしてもその適当量は一 当然のとととも考元られるが-一成 長の面で結果的に anabolic 亿作用 しているてとを意味しているものと みなされる。また， $\mathrm{DHA}+\mathrm{COL}+$ DOG 群ではその增加量は平均 53.6 gであつたが，乙のことはDHA 投 与により,強く増大した組織が COL の作用で，いわば balance のとれ た成長をするととを意味しているのではないかと考光られ，正常の発育には DHA と COL との相互の作 用が必要であるととを示唆していると思われた。

\section{2、骨・筋および皮膚・脂肪の湿および乾燥重量に及ぼす影響}

DHA および COL 投与が両側副腎雌ラットの骨・筋，皮膚・脂肪の湿一抢上び乾燥一重量に及ぼす影響 は Table 5 および Fig. 3 亿示す如くであつた.

各群の屠殺時体重は, 前記の体重增加傾向と同様であり, また骨・筋湿重量は, DOC 投与群, DHA 投与 群， COL 投与群， DHA + COL 投与群， steroid 非投与群，および副腎非摘除対照群ではそれぞれ平均 89.6，98.8，90.6，94.4，65.2，および91.8 g と，体重同様 DHA 投与群では DOC 単独投与対照群に比 し明らかに骨および筋の肥大增殖がみられ，また乾燥重量氾いてても各群それぞれ平均 $27.0 ， 30.2 ， 27.8$, 29.3，20.1，および $28.6 \mathrm{~g}$ と DHA 投与群において明らかな重量増大がみられた。 その他の群においても 体重増加と同様の傾向を示した。また，骨・筋の体重に対する比率は各群ともほぼ同一で平均 56 ～57\%を占 めたが， steroid 非投与群では $51 \%$ とや減少を示した。骨・筋乾燥重量の湿重量に対する比率は各群とも 平均 30 ３1\%であり，すなわち，骨・筋の水分量は約 $70 \%$ であつた，皮䖉および皮下脂肪など脂肪組織の湿 重量の各群の平均はそれぞれ $26.8 ， 28.6 ， 26.4 ， 27.6 ， 23.8$ おご $25.2 \mathrm{~g}$ であり，体重の增加と同様傾向を 示し，それらの乾燥重量も湿重量と同椂傾向であつた。これらのととは両側副筒摘除ラットにDHA を投 与した際にみられる発育促進は，身体各部分が 2,3 蔵器を除いてほほ balance を保つて発育するととを 意味しており，また異常な水分蓄留や脂肪過多の起らないととを示している.

\section{3. 肝・腎・包皮腺その他臓器重量に及ぼす影響}

DHA および COL 投与の両側副腎摘除雌ラットの 2, 3 の臟器重量に及ばす影響は Table 6 および Fig. 4 
飞示す如くであり, 肝重量は DOC 投与群, DHA 投与群, COL 投与群, DHA + COL 投与群, steroid 非投与群，および副粲非摘除群ではそれぞれ 平均 8.64，11.06，8.84，11.25，5.30および $9.56 \mathrm{~g}$ であり， DHA 投与群および DHA + GOL 群では著明な肝重量の増加が認められ，また steroid 非投与群の肝重量 は著しく減少していた。 なお肝重量の体重 $100 \mathrm{~g}$ 当りの比重量も各群平均それぞれ 5.47,6.37, 5.50, 6.65, 4.16, および5.89g と同様の変化を示した。 このととは, 副腎摘除や DHA 投与により，まず肝に変化が 起り, その蛋白合成ないし代謝機序の変化て次で全身各組織の蛋白代謝が変化するととを示唆しているもの とみなされる。

腎重量は各群それぞれ平均 $1.46,1.56,1.42,1.57,1.10$ よび $1.48 \mathrm{~g}$ で, 肝重量同様, DHA 投与群お よび DHA+COL 投与群において重量増加がみられたが，体重に対する比重量には著変がみられなかつた。

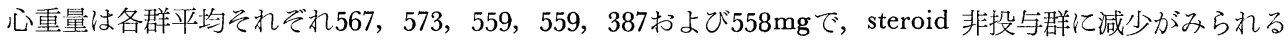
他は各群に著明な差は認められなかつた，脳重量もまた同様 steroid 非投与群以外は著差はみられなかつ た.

Table 6. Effects of DHA and cortisol on the weight of organs in the adrenalectomized female rats

\begin{tabular}{|c|c|c|c|c|c|c|c|c|}
\hline \multirow[b]{2}{*}{ Group } & \multirow{2}{*}{\multicolumn{2}{|c|}{ Organ }} & \multirow[b]{2}{*}{ Liver } & \multirow[b]{2}{*}{ Kidney } & \multirow[b]{2}{*}{ Heart } & \multirow[b]{2}{*}{ Brain } & \multicolumn{2}{|c|}{ Preputial Gland } \\
\hline & & & & & & & $\begin{array}{l}\text { with } \\
\text { Contents }\end{array}$ & $\begin{array}{l}\text { without } \\
\text { Contents }\end{array}$ \\
\hline \multirow{4}{*}{$\begin{array}{l}\text { 1. DOG } \\
\text { (Cont- } \\
\text { rol) }\end{array}$} & $\mathrm{a}$ & Average Absolute wt. (mg) & 8637 & 1459 & 565 & 1598 & 80.0 & 58.8 \\
\hline & $\mathrm{b}$ & Standard Error (mg) & 311 & 55 & - & - & 1.6 & 1.1 \\
\hline & c & Wt./100g of Body wt. (mg) & 5473 & 925 & 358 & 1013 & 50.7 & 37.3 \\
\hline & d & Difference from DOC-group*(\%) & 0.0 & 0.0 & 0.0 & 0.0 & 0.0 & 0.0 \\
\hline \multirow{4}{*}{$\begin{array}{l}\text { 2. DOC } \\
+ \text { DHA }\end{array}$} & a & Aver. Absol. wt. (mg) & 11064 & 1557 & 573 & 1685 & 135.4 & 87.8 \\
\hline & b & S.E. $(\mathrm{mg})$ & 479 & 44 & - & - & 12.9 & 9.4 \\
\hline & $\mathrm{c}$ & Wt./100g of Body Wt. (mg) & 6373 & 902 & 330 & 971 & 78.0 & 50.8 \\
\hline & d & Difference from DOC-group $(\%)$ & +28.1 & +6.7 & +1.4 & +5.4 & +69.3 & +49.3 \\
\hline \multirow{4}{*}{$\begin{array}{l}\text { 3. DOC } \\
+ \text { COL }\end{array}$} & a & Aver. Absol. Wt. (mg) & 8836 & 1417 & 559 & 1617 & 91.8 & 64.2 \\
\hline & b & S.E. $(\mathrm{mg})$ & 305 & 28 & - & - & 10.1 & 4.7 \\
\hline & c & Wt./100g of Body Wt. (mg) & 5502 & 882 & 348 & 1007 & 57.2 & 40.0 \\
\hline & $\mathrm{d}$ & Difference from DOC-group (\%) & +2.3 & -2.9 & -1.1 & +1.2 & +14.8 & +9.2 \\
\hline \multirow{4}{*}{$\begin{array}{l}\text { 4. DOC } \\
+ \text { DHA } \\
+ \text { COL }\end{array}$} & a & Aver. Absol. Wt. (mg) & 11245 & 1571 & 559 & 1668 & 169.0 & 107.4 \\
\hline & $\mathrm{b}$ & S.E. $(\mathrm{mg})$ & 288 & 31 & - & - & 9.8 & 6.4 \\
\hline & c & Wt./100g of Body Wt. (mg) & 6646 & 928 & 330 & 986 & 99.9 & 63.5 \\
\hline & d & Difference from DOG-group (\%) & +30.2 & +7.7 & -1.1 & +4.4 & +1113 & +82.7 \\
\hline \multirow{4}{*}{$\begin{array}{l}5.1 \% \\
\text { NaCl } \\
\text { alone }\end{array}$} & a & Aver. Absol. Wt. (mg) & 5302 & 1095 & 387 & 1429 & 61.8 & 43.2 \\
\hline & $\mathrm{b}$ & S.E. (mg) & 465 & 64 & - & - & 8.6 & 7.6 \\
\hline & c & Wt. $/ 100 \mathrm{~g}$ of Body Wt. (mg) & 4155 & 858 & 303 & 1120 & 48.4 & 33.9 \\
\hline & $\mathrm{d}$ & Difference from DOC-group (\%) & -38.6 & -24.9 & -31.5 & -10.6 & -22.7 & -26.5 \\
\hline \multirow{4}{*}{$\begin{array}{l}\text { 6. Non- } \\
\text { adrenal- } \\
\text { ectomiz- } \\
\text { ed Rats }\end{array}$} & a & Aver. Absol. Wt. (mg) & 9556 & 1478 & 558 & 1623 & 108.0 & 78.4 \\
\hline & b & S.E. $(\mathrm{mg})$ & 395 & 41 & - & - & 4.3 & 2.8 \\
\hline & c & Wt./100g of Body Wt. (mg) & 5891 & 911 & 344 & 1001 & 66.6 & 48.3 \\
\hline & d & Difference from DOG-group (\%) & +10.6 & +1.3 & -1.2 & +1.6 & +35.0 & $+33,3$ \\
\hline
\end{tabular}

* Difference from DOG-group in absolute weight 
Fig. 4. Effects of DHA and cortisol on the weight of organs in the adrenalectomized female rats

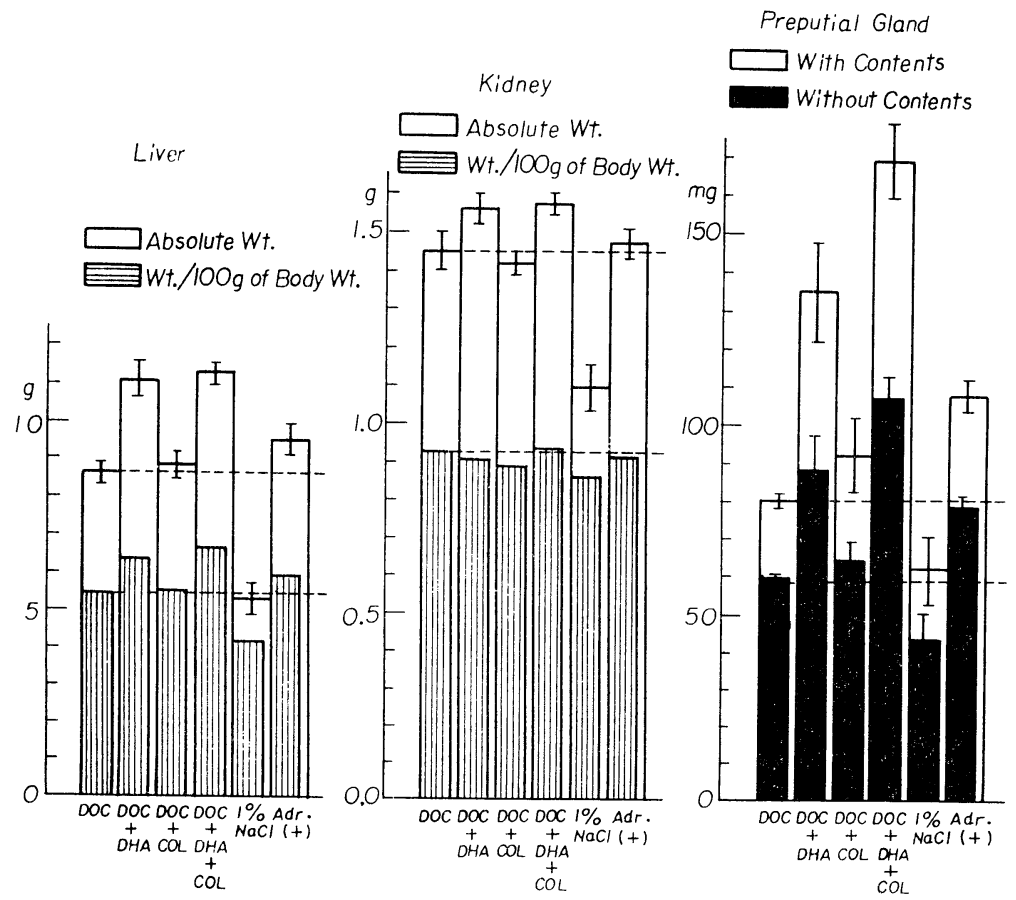

DHA 投与による肝および腎の肥大は DHA の蛋白同化作用の現れとみなすととができ，また，生体内 における生理的状態での蛋白同化および異化に DHA および COL か滵接に関与してものとみなされる.

包皮腺 preputial gland 重量は，内容を含んだ全重量は各群それぞれ平均80，135，92，169，62および $108 \mathrm{mg}$ であり。また内容を除去した重量はそれでれ平均59，88，64，107，43および78mgであり，いずれも DHA 投与群では著明に包皮腺は肥大し，内容も増大し，DHA に COL を添加した群では更に増大する 傾向が認められた．また COL 投与群でも DOC 単独投与対照群よりも重量増大傾向を示した. steroid 非 投与群では減少した。このととは DHA の雌ラットの性的な面に及ぼす作用の重要な一つといえ，ひいて は副腎が種族保存の面でも間接的に重要な作用を果しているととを示す一証左ともいえよう。

\section{$\mathrm{V}$ 考察}

生体の成長発育および老化は, 内分泌学的観点からは勾論, 一般的にみても強いホルモンの control 下に あるといつて過言でないのであろう. 全身の殆んどの細胞は, 神経細胞や卵子など一部のものを除いては, 常に新らたに再生され，いわばたえず新らしい細胞と交代しているとされるが，その再生の状態は完全に同 一ではなく，漸次加令および老化（aging）の不可逆的な一路をたどる．現在この不可逆的な老化を停此あ るいは可逆的にする決定的な方法はみられないが，乙れ支配するものの一つにホルモンがあることは誤り ないようであるから，てれら aging の内分泌学的考究は将来，再生しえない紐胞は別として，一般の細胞の aging の不可逆性を変化せしめる可能性をも含んでいるといえよう.

これら成長発育老化に密接に関与する種々のホルモンの内著者は女子副腎からも多量に分泌されるいわゆ る副腎性 androgen とくに DHA についていくつかの考察を加えてきている ${ }^{2) ー 7) . ~}$

DHA は㨁接副腎より多量に分泌され, 遊離 free の形でも分泌されるが,近年硫酸基と結合した sulphate 
として水溶性のいわゆる結合型 conjugate form としても分泌するとされ，その作用および意義か注目をあ びてきている。

DHA の生理学的意義については, 他の steroids すなわち androsterone, etiocholanolone, testosterone さらに最近では estriol などの重要な precursor として注目されているが，また著者の本編の実験その他の 如く，かなりの蛋白同化作用や性機能住対する諸作用を有しており，女子における骨・筋の発育代謝，正常 な性機能の維持, 外陰・陰毛の発育, 性的行動などに DHA や副腎性 androgen が密接に重要な役割を果 している.

一般的にひとつの steroid hormone を投与した場合, 現れた作用が，投与 steroid 自身の作用によるも のかそれともそれより convert された steroid の作用によるものかを決定するてとは，生体内での steroid hormone の中間代謝産物 metabolite が完全に分つていない今日必ずしも容易でないとともすくなくない. すなわち現在未知の，作用のより強い物質が metabolite として血中または組織中に将来見出される可能性 もあり，また desoxycorticosterone と aldosterone との関係の様に新らしい有効 steroid が将来更に見出 されるかも知れない.

従つて, 投与された steroid が最終的に細胞内でどの様な形で物質代謝に関与しているのかその作用機序 の殆んど全く未解明の現段階では，ある steroid を投与して現れる現象をもつてその steroid の作用とみな すことは，その範囲の決定の問題はあるとしても，止むをえないととであらう。

生体内および尿中に見出される steroid 代謝産物は近年ますますその数は激増しており, 将来はさらに複 雑詳細になるものとみなされるが，それらのいずれが生体内で有効でいずれが無効かを決定するてとは見方 によつては不可能とさえいえるように思われる。すすおわ， steroid は一般にそれぞれいくつかのいわば多 面的な性質や作用を有しており，単純に1，2の作用の強弱の比較によつて強い方がより重要と決定するの は生体の本来の姿を見誤る危険性を多く含んているのではなからうか.

考光様によつては生体は無䭾なととは一切しておらず，生体内のすべての物質はそれぞれ意義を有してお り，作用の弱い物質はそれなりに他の面で特色を有し，またある場合には作用が微弱あるいは緩除であるて とが生体にとつて極めて有用であることも多いとみなすてとができる。たとえば estradiol および estrone の単なる代謝終末産物としてその意義を殆んど無視されていた estriol が近年女子にとつて大切な steroid であると認識され注目されてきたてとも，ての様な意味で steroid hormone の研究に多くの教訓を与えて いるように思われる。周知の如く estradiol の作用はかなり強く，月経周期において子宮内膜を急速に再生 せしめるが，一方その急激な内膜細胞増殖作用は時として内膜の異常增殖を起させ，また癌を promote す ることがある。すなわち，生体にとつては単に強力，急激な作用を有するもののみが大切なのではないと考 えられる。

てれらをDHA について考察すると，DHA 投与時に現れる作用は，一面では対称的である cortisol の 作用に比すると微弱であり，いわば緩徐な作用の現れ方をするが，乙のととも生理学的観点からみれば一応 首肯しうるように思わ机る。すすなわち, cortisol は乫然の激烈な stress に対して速やかに反応し, 生体内の 状態を急速に変じて stress に対処し，自己防衛しなければならないが，一方，DHA は蛋白同化および性 機能面においても，短時間内の急激な作用は必要でなく，急激な異常增殖を起すてとなく，徐々に着実に正 常状態へ回復あるいはさらに成長するととが重要と考えられ，DHA はその目的によく適合した steroid と みなされ，場合によつてはその balance において cortisol の作用を control している感もある.

DHA 亿由来するいわゆる副腎性 androgen には androsterone, etiocholanolone また testosterone な ど種々のものが含ま机るか，乙れらはそ机で個有の作用を有しており，単純にてれらのうちいずれか1つ のみあれば他は全く不用であるとか，それらのうちいずれが最も重要かというととの論義は，前述のような 観点からも必ずしも容易ではなく，すくなくとも数種類のものがそれぞれの特徵を発揮しながら，成長や aging 亿関与しているものと考元るのが妥当と思われる．同様に本実験の様に DHA を投与した場合に現 れる変化も最後まで DHA として作用しているのか convert された他 steroid が現している作用なのかを 
断定するととは必ずしも容易でなく，乙のととは未発見の metabolite を仮定すればすべての sterid 投与 実験についていえるてとであり, 従つて現れた作用を総合して投与されたDHAの作用ひいては内因性 DHA も同様の作用を有するとみなすのも，生体という広い観点からみれば一応適当と考朰れる。

なお，極めて仮説的ではあるが， steroid 代謝において，全 steroid t在 (1)内分泌㵴器より直接分泌され 一部尿中に排泄されるまでそのままの形を保つているもの，(2)分泌されるが尿中に現れないもの，(3)尿中に は存在するが分泌されないもの，(4)分泌・排泄されない中間代謝産物群の 4 群に分類したとすると，(1)の直 接分泌され尿中に排泄される群すなわちすくなくとも一部は分泌された原形のまま生体内を循環して尿中に 排泄るされ estradiol, estrone, dehydroepiandrosterone その他の steroid はすべて一般的に生体に重要な 作用を有し，その他の群では重要なものと比較的そうでないものとが混在しているように思われる.

また前記の様に DHA に由来する steroids のうち DHA を含めて大部分のものがいわゆる副腎性「男 性ホルモン」 adrenal 'androgen’として一括されているが，乙の名称はある場合には理解をたすけるかも知 れないが，乙の群の steroid の中には DHA のように男化作用が極めて弱く anabolic 作用のかなりある のもあり，またその他いくつかの作用を示す steroid もある。従つててれらを ‘androgen’ と呼ぶのは必ず しも適当でないように思われ，また女性にも「男性ホルモン」がかなり多量（男性の約 $2 / 3 ）$ あるというよ うな表現もいわば矛盾した表現であり，頳 ${ }^{19}$ の強調するように男性ホルモンという表現によつて研究面で も無意識的に禍いされている面もすくなくない.

従つて各 steroid の構造の明らかな今日，すくなくとも研究面では構造的特徵たとえば $\mathrm{C}_{19}$ steroid など という表現で分類するのが好ましいと考学る。

DHA 投与により両側副腎摘除雌ラットの体重は増加したが，このととはヒトにおいても同様とみなしう るであろう。ただヒトでは性的成熟後は肉体的発育はかなり程度を減ずるが，ラットでは性的成熟後も肉体 的発育が統き，性周期発来時の 3 倍前後の体重まで成長発育する。乙れは成長ホルモン，副腎性 androgen， 性腺由来ホルモンその他の相互の関連性の相違によるものであろう。このように成長という1つの目標に種 々の諸要素が作用しあい調節しあつているわけであるが，乙れら副腎性 androgen と他ホルモンとの関連性 および成長発育との関係については，比較内分泌学的考察と共にさらに追究すべき多くの間題を含んでいる. なお，本実験成績からも DHA の分泌減少ないし久除が老化に結びつくことは容易に推測され，老化の問 題にも DHA は重要な意義を有するものとみなされる.

\section{IV 総 括}

副腎より多量に分泌される Dehydroepiandrosterone (DHA) ひいては副腎性 androgen が女子の成長発 育または老化に及ぼす作用を推知する目的で，DHA を雌ラットに投与し，その成長発育，臟器重量变化な ぞを検討し，副腎の有無，cortisol (COL) 添加の影響などについて種々検討した.

（1）正常雌ラットに DHA 1 日 $2 \mathrm{mg} 2$ 週間投与した結果では，対照群に比しやや体重增加が著しい傾向 の認められる場合もあるが，殆んど全く著変のない場合もあり一定せず，まだ去勢ラットでも同様の結果が 得られた。DHA 投与群では対照群に比し, 副腎および䏩腺重量の減少が認められた。

（2）同腹雌ラットを両側副腎摘除後 desoxycorticosterone acetate（DOC）を投与して延命せしめ，乙れ に DHA を投与した結果，対然群に比し著しい体重増加を示し，その骨・筋の湿-，乾燥重量も同様の結果 を示した.

すなわち，(1) DOC 単独投与群，(2) DHA 投与群，(3) COL 投与群，(4) DHA + COL 投与群，(5) steroid 非投与群，および(6)副腎非摘除刘照群の体重增加量はそれぞれ平均41.4，67.2，51.6，53.6，18.2， および $48.8 \mathrm{~g}$ であり, DHA 投与群に著しい体重増加が認められた。また, 骨・筋湿重量は各群平均ぞれそ

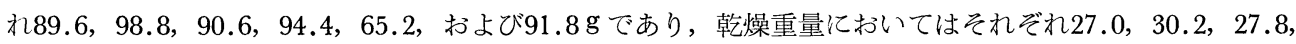
29.3，20.1，および28.6 g であり，DHA 投与群では対照群に比し明らかな骨・筋の肥大増殖がみられた。

(3) 肝実重量は各群それぞれ平均8.64，11.06，8.84，11.25，5.30および $9.56 \mathrm{~g}$ であり，体重 $100 \mathrm{~g}$ 当り 


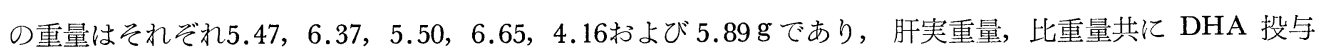
群および DHA+COL 投与群において著明な増加が認められ，また DHA に COL を添加投与すること により有意差ではないが肝重量がやや増加する傾向がみられ，肝の正常な発育および肝における protein anabolism に DHA と COL との相互の作用が重要であるととが示唆された.

（4）腎重量も DHA 投与群および DHA+COL 投与群において重量増加がみられたが，体重に対する 比重量には著変が認められなかつた,

また，心，脳重量には steroid 非投与群以外は著差がみられなかつた。

（5）包皮腺重量は内容を含んだ全重量は各群それぞれ平均 $80 ， 135 ， 92 ， 169 ， 62 お よ ひ ゙ 108 \mathrm{mg}$ でり，ま

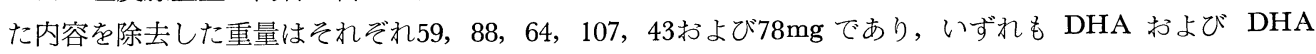
+COL 投与群に著明な肥大が認められ，とくに DHA に COL を添加するととにより著しく増大する傾 向が認められた.

(6) 雄ラット肛門挙筋肥大で表した DHA のいわる蛋白同化能は testosterone propionate (TP) の平均 $37.4 \%$ であるのに比し，男化能は TP のわずか $1.7 \%$ にすぎず，本実験条件における DHA の anabolic androgenic ratio は TP の約21倍であつた.

（7）以上の結果から DHA は他 steroid の precursor であるのみならず，かなりの anabolic 作用を有 し，その作用は緩徐ではあるが，生体の代謝に COL と共に重要な作用を営み，また性的にも密接な関連 性を有することが確認され，乙れらから女子の成長発育および sexual behavior にも DHA は直接的間接 的に重要な役割を果しているであろうことが推測され，それらについて種々考察が加えられた。

終始御懇篤な御指導と御鞭撻並びに御校閲を睗わつた恩師赤須文男教授に樑く感謝致します.

\section{文献}

1) KOCHAKIAN, G.D. : Endocrinology, $21: 750$, (1937).

2）赤須文男 : 産婦の世界, $16: 365$,

(1964).

3）赤須文男：産婦治療，9：45，(1964）,

4) 西田悦郎：日産婦誌, $15: 1151$,

(1963).

5）西田悦郎：日産婦誌，18:285, (1966).

6) 西田悦郎: 日産婦誌, $18: 383$,

(1966).

7）西田悦郎：日産婦誌，18:1275，(1966).

8) KORENGHEVSKY, V. \&

M, DENNISON : Biochem. J., 30 : 1514, 1936.

9) VARON, H.H. \& J.J. GHRISTIAN :

Endocrinology, $72: 210$, (1963).

10) EISENBERG, E. \& G.S. GORDAN : J. Pharmacol.

Exp. Ther., 99 : 38, (1950).

11) HERSGHBERGER, L.G., E.G. SHIPLEY \& R.K. MEYER :

Proc. Soc. Exp. Biol. Med., 83 : 175, (1953).

12) SCOW, R.O. Endocrinology, $51: 42$, (1952).

13) SCOW, R.O. \& S.N. HAGAN : Endocrinology, $60: 273$, (1957).

14) NIMNI, M.E. \&

E. GEIGER : Proc. Soc. Exp. Biol. Med., 94 : 606, (1957).

15) HAYES K.J. : ACTA ENDOGR., $48: 337$, (1965). $\quad$ 16) KOGHAKIAN, C.D., G. TILlOTSON, J. AUSTIN, E. DOUGHERTY, V. HAAG \& R. COALSON : Endocrinology, 58 : 315, (1956).

17) GREENE, E.C. : Anatomy of the Rat, (1935), p. 79, p. 102, Amer. Philos. Soc., Phil. 18）小林隆，木下国昭， 小菅庸二 : 内分泌之代謝, $3: 300,(1962)$.

19）赤須文男：内分泌之代謝，3：293，（1962）. 